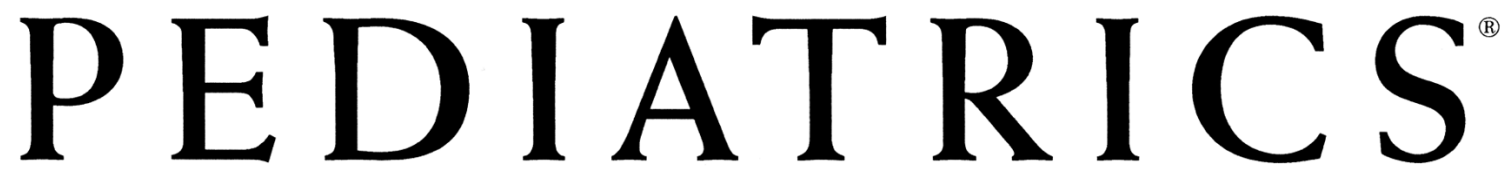

OFFICIAL JOURNAL OF THE AMERICAN ACADEMY OF PEDIATRICS

\title{
Psychosocial Health Among Young Victims and Offenders of Direct and Indirect Bullying
}

Marcel F. van der Wal, Cees A. M. de Wit and Remy A. Hirasing Pediatrics 2003;111;1312

The online version of this article, along with updated information and services, is located on the World Wide Web at: http://pediatrics.aappublications.org/content/111/6/1312.full.html

PEDIATRICS is the official journal of the American Academy of Pediatrics. A monthly publication, it has been published continuously since 1948. PEDIATRICS is owned, published, and trademarked by the American Academy of Pediatrics, 141 Northwest Point Boulevard, Elk Grove Village, Illinois, 60007. Copyright (c) 2003 by the American Academy of Pediatrics. All rights reserved. Print ISSN: 0031-4005. Online ISSN: 1098-4275.

\section{American Academy of Pediatrics}

DEDICATED TO THE HEALTH OF ALL CHILDREN ${ }^{\mathrm{m}}$ 


\title{
Psychosocial Health Among Young Victims and Offenders of Direct and Indirect Bullying
}

\author{
Marcel F. van der Wal, PhD*; Cees A. M. de Wit, PhD§; and Remy A. Hirasing, PhDłII\|
}

\begin{abstract}
Objective. To assess the association between bullying (both directly and indirectly) and indicators of psychosocial health for boys and girls separately.

Study Design. A school-based questionnaire survey of bullying, depression, suicidal ideation, and delinquent behavior.

Setting. Primary schools in Amsterdam, The Netherlands.

Participants. A total of 4811 children aged 9 to 13.

Results. Depression and suicidal ideation are common outcomes of being bullied in both boys and girls. These associations are stronger for indirect than direct bullying. After correction, direct bullying had a significant effect on depression and suicidal ideation in girls, but not in boys. Boy and girl offenders of bullying far more often reported delinquent behavior. Bullying others directly is a much greater risk factor for delinquent behavior than bullying others indirectly. This was true for both boys and girls. Boy and girl offenders of bullying also more often reported depressive symptoms and suicidal ideation. However, after correction for both sexes only a significant association still existed between bullying others directly and suicidal ideation.

Conclusions. The association between bullying and psychosocial health differs notably between girls and boys as well as between direct and indirect forms of bullying. Interventions to stop bullying must pay attention to these differences to enhance effectiveness. Pediatrics 2003;111:1312-1317; bullying, depression, suicidal ideation, delinquency, children.
\end{abstract}

$\mathrm{B}$ ullying is generally viewed as a specific form of aggression. Most authors describe bullying as repeated and lasting negative actions of 1 or more children (the offender[s]) directed to a specific child (the victim). The victims are typically not able to defend themselves. ${ }^{1}$ Some authors make a distinction between direct (overt) bullying and indirect (covert, relational) bullying. Direct bullying includes all sorts of physical and verbal aggression, such as kicking, hitting, threatening, name-calling, and insulting. Indirect bullying includes aspects of social isolation such as ignoring, excluding, and backbiting. Direct bullying is more frequent in boys, indirect bullying

From Departments of *Epidemiology and Health Promotion and $\ddagger$ Child Health Care, Municipal Health Service Amsterdam, §Department of Developmental Psychology, University of Nijmegen, IIMedical Center, Free University, and \|Department of Social Medicine, Institute for Research in Extramural Medicine, Amsterdam, The Netherlands.

Received for publication May 22, 2002; accepted Nov 12, 2002.

Reprint requests to (M.F.v.d.W.) Department of Epidemiology and Health Promotion, Municipal Health Service Amsterdam, P.O. Box 2200, 1000 CE Amsterdam, The Netherlands. E-mail: mvdwal@gggd.amsterdam.nl PEDIATRICS (ISSN 0031 4005). Copyright (C) 2003 by the American Academy of Pediatrics. more frequent in girls. ${ }^{2-5}$ The prevalence of being bullied among children decreases with age and varies according to ethnic origin. ${ }^{2,3,6}$

Bullying has a negative impact on psychosocial health. Being repeatedly bullied has been associated with an increased risk of depression, ${ }^{7-13}$ suicidal ideation, ${ }^{8}$ and loneliness. ${ }^{14}$ Being a bully is also associated with poorer health outcomes. For example, delinquency (in later life) and depression has been linked to being a bully. ${ }^{6,8,15}$ It is possible that the impact of bullying differs for girls and boys and for direct and indirect bullying. However, bullying research has mainly been focused on boys and on physical and verbal forms of bullying. Only recently has the focus also shifted to girls and indirect forms of bullying.

In this study, we investigated the association between direct and indirect bullying and 3 indicators of psychosocial health (depression, suicidal ideation, and delinquency) among children aged 9 to 13 years in Amsterdam, The Netherlands. The results are presented separately for boys and girls. The relation between direct and indirect bullying and sociodemographic factors will be described in another paper.

\section{METHODS}

In the school year 2000-2001, the department of Child Health Care of the Municipal Health Service approached all 199 primary schools in Amsterdam, The Netherlands, to participate in the study. The schools were approached by their own school nurse visiting the schools personally. Data on bullying, psychosocial health (depression, suicidal ideation, and delinquency), and sociodemographic factors were collected by self-report questionnaires. The questionnaires were administered to pupils in the 7th and 8th grade, and were completed in the classroom under supervision of the teacher. Participation was anonymous, and parents had been asked permission previously by passive consent procedures.

Bullying was measured using the Amsterdam Children's Bullying questionnaire which has good reliability and validity. ${ }^{16}$ This questionnaire has 2 subscales, 1 about bullying ( 20 items) and 1 analogous subscale about being bullied ( 20 items). Each subscale comprises 12 items measuring the direct bullying of others $(\alpha=$ .84 ) or directly being bullied ( $\alpha=.86)$, and 8 items measuring the indirect bullying of others $(\alpha=.75)$ or indirectly being bullied ( $\alpha=.86)$; for example, "They hit or strike me" and "They pretend they don't hear or see me". Items were scored on a 4-point scale $(0=$ never, $1=$ now and then, $2=$ often, and $3=$ very often $)$. The higher the score, the more the child is a bully or is being bullied. The total score on each subscale is divided by the number of items of the subscale. We trichotomized direct and indirect bullying around the 50th and 90th percentiles to create 3 categories: "(almost) never", "sometimes", and "frequently". The questions about being bullied were preceded by the following text: "Many children are sometimes bullied. Bullying can be done in many ways, such as name-calling and taking away something from someone. The following questions are about how often you are 
bullied by other children.". The same kind of text preceded the questions about bullying other children.

Depression was measured using the Short Depression Inventory for Children $(\alpha=.73) .{ }^{17}$ This questionnaire is designed for screening purposes, and does not allow full depression diagnoses. The questionnaire consists of 9 items with "true" and "not true" as response categories (for example, "I have been feeling rather sad lately"), and scores can vary between 0 and 9 . The questionnaire has demonstrated excellent psychometric properties, ${ }^{18}$ and has been extensively validated among primary school children in The Netherlands. ${ }^{19,20}$ In accordance with De Wit and Kroesbergen,19 children who scored from 6 to 9 were classified as being depressed.

Suicidal ideation was measured by 2 questions with false-true answers as well ( $\alpha=.74)$. The questions asked were "Lately I have been thinking: I wish I were dead" and "Lately I have been thinking: I am going to kill myself". We classified children who had answered true on both questions as having suicidal ideation.

Delinquency was measured by an 11-item questionnaire on delinquent behavior $(\alpha=.68)$ and was constructed specially for this study (for example, "Taking something from a shop without paying"). Items about delinquency were hidden within a set of other, more neutral items about leisure activities, and were scored on a 5 -point scale ( $4=$ (almost) every day, $3=$ every week, $2=$ every month, 1 = less often, $0=$ never). The higher the score, the more the child is expected to display delinquent behavior. Children who had scores above the 90th percentile were coded as having serious delinquent behavior.

Sociodemographic information included sex, age, family structure (whether the child was living with both or 1 natural parent), socioeconomic status (whether both parents were unemployed), and ethnic origin. Ethnic origin was defined according to the mother's country of birth: The Netherlands, Surinam (former Dutch colony in South America), Morocco, Turkey, and other countries.

$\chi^{2}$ tests were used to examine univariate associations between bullying and the 3 psychosocial health indicators. Logistic regression was used to determine multivariate associations between bullying and psychosocial health. A separate model was fitted for each outcome: depression, suicidal ideation, and delinquency. The independent variables entered were age, family structure, ethnic origin, socioeconomic status, directly and indirectly bullying others, and directly and indirectly being bullied. Analyses were performed separately for boys and girls.

\section{RESULTS}

\section{Sample Characteristics}

Of all 199 primary schools, 104 participated in the study with a total of 6635 pupils in the 7th and 8th grade. Overall, from 1195 pupils (18.0\%) we did not receive a questionnaire, and 719 pupils $(10.8 \%)$ did not respond to 1 or more questions. Therefore, this study is based on the remaining 4721 questionnaires $(71.2 \%)$ suitable for analysis. There were $49.5 \%$ boys and $50.5 \%$ girls in the sample. The age distribution was as follows: $22.2 \%$ children aged 9 to 10 years, $44.2 \%$ children aged 11 years, and $33.6 \%$ children aged 12 to 13 years. Dutch pupils accounted for $43.0 \%$ of the sample, Surinamese for $14.9 \%$, Moroccan for $15.9 \%$, Turkish for $9.0 \%$, and $17.2 \%$ were of different ethnic origin. Of all of the children, $68.3 \%$ lived with both natural parents, $19.8 \%$ lived with 1 natural parent (generally the mother), $7.4 \%$ lived with 1 natural parent and 1 substitute parent (in most cases a stepparent), and the remaining $4.4 \%$ lived apart from parents. According to $8.8 \%$ of the respondents, both parents were unemployed. However, $9.5 \%$ of the children did not know the (un)employed status of their parents.

\section{Being Bullied and Psychosocial Health}

Tables 1 and Table 2 present for boys and girls, respectively, the associations between being bullied and indicators of psychosocial health. For boys and

TABLE 1. Crude and Adjusted Odds Ratios for the Association Between Being Bullied and Depression, Suicidal Ideation, and Delinquent Behavior, Respectively-Boys

\begin{tabular}{|c|c|c|c|c|c|}
\hline $\begin{array}{l}\text { Boys Being } \\
\text { Bullied }\end{array}$ & $\%$ & $\begin{array}{c}\text { Crude } \\
\text { Odds Ratio }\end{array}$ & $95 \% \mathrm{CI}$ & $\begin{array}{c}\text { Adjusted } \\
\text { Odds Ratiot }\end{array}$ & $95 \% \mathrm{CI}$ \\
\hline \multicolumn{6}{|l|}{ Depression } \\
\hline Directly & * & & & & \\
\hline (Almost) Never & 3.1 & 1 & & 1 & \\
\hline Sometimes & 7.5 & 2.57 & $1.69-3.90$ & 1.30 & $.79-2.10$ \\
\hline Frequently & 22.4 & 9.13 & $5.63-14.8$ & 1.91 & $.99-3.65$ \\
\hline Indirectly & $*$ & & & & \\
\hline (Almost) Never & 2.1 & 1 & & 1 & \\
\hline Sometimes & 8.1 & 4.14 & $2.60-6.70$ & 3.40 & $2.02-5.70$ \\
\hline Frequently & 27.7 & 18.10 & $10.9-30.1$ & 11.14 & $5.86-21.2$ \\
\hline \multicolumn{6}{|l|}{ Suicidal ideation } \\
\hline Directly & * & & & & \\
\hline (Almost) Never & 3.3 & 1 & & 1 & \\
\hline Sometimes & 6.7 & 2.13 & $1.40-3.23$ & 1.07 & $.66-1.73$ \\
\hline Frequently & 13.4 & 4.61 & $2.71-7.84$ & 1.07 & $.53-2.15$ \\
\hline Indirectly & * & & & & \\
\hline (Almost) Never & 2.7 & 1 & & 1 & \\
\hline Sometimes & 6.8 & 2.67 & $1.73-4.12$ & 2.09 & $1.28-3.41$ \\
\hline Frequently & 17.8 & 7.88 & $4.74-13.1$ & 5.58 & $2.89-10.8$ \\
\hline \multicolumn{6}{|c|}{ Delinquent behavior } \\
\hline \multicolumn{6}{|l|}{ Directly } \\
\hline (Almost) Never & 14.4 & 1 & & 1 & \\
\hline Sometimes & 15.3 & 1.07 & $.85-1.37$ & .61 & $.46-.83$ \\
\hline Frequently & 11.9 & .81 & $.51-1.28$ & .20 & $.11-.37$ \\
\hline \multicolumn{6}{|l|}{ Indirectly } \\
\hline (Almost) Never & 13.6 & 1 & & 1 & \\
\hline Sometimes & 14.9 & 1.12 & $.88-1.43$ & .81 & $.60-1.08$ \\
\hline Frequently & 18.8 & 1.48 & $1.00-2.18$ & 1.27 & $.76-2.13$ \\
\hline
\end{tabular}

CI indicates confidence interval.

* $P<.05$.

+ Adjusted for sociodemographic variables, being bullied directly or indirectly, and bullying others directly and indirectly. 
TABLE 2. Crude and Adjusted Odds Ratios for the Association Between Being Bullied and Depression, Suicidal Ideation, and Delinquent Behavior, Respectively-Girls

\begin{tabular}{|c|c|c|c|c|c|}
\hline $\begin{array}{l}\text { Girls Being } \\
\text { Bullied }\end{array}$ & $\%$ & $\begin{array}{c}\text { Crude } \\
\text { Odds Ratio }\end{array}$ & $95 \% \mathrm{CI}$ & $\begin{array}{c}\text { Adjusted } \\
\text { Odds Ratio† }\end{array}$ & $95 \% \mathrm{CI}$ \\
\hline \multicolumn{6}{|l|}{ Depression } \\
\hline Directly & * & & & & \\
\hline (Almost) Never & 6.4 & 1 & & 1 & \\
\hline Sometimes & 16.3 & 2.84 & $2.14-3.76$ & 1.50 & $1.08-2.09$ \\
\hline Frequently & 42.6 & 10.84 & $7.15-16.4$ & 3.29 & $1.95-5.54$ \\
\hline Indirectly & $*$ & & & & \\
\hline (Almost) Never & 3.6 & 1 & & 1 & \\
\hline Sometimes & 13.6 & 4.22 & $2.88-6.19$ & 3.52 & $2.32-5.34$ \\
\hline Frequently & 35.1 & 14.45 & $9.57-21.8$ & 8.90 & $5.40-14.7$ \\
\hline \multicolumn{6}{|l|}{ Suicidal ideation } \\
\hline Directly & * & & & & \\
\hline (Almost) Never & 4.1 & 1 & & 1 & \\
\hline Sometimes & 11.3 & 2.99 & $2.13-4.22$ & 1.72 & $1.15-2.57$ \\
\hline Frequently & 24.8 & 7.74 & $4.75-12.6$ & 2.62 & $1.41-4.88$ \\
\hline Indirectly & * & & & & \\
\hline (Almost) Never & 3.5 & 1 & & 1 & \\
\hline Sometimes & 8.5 & 2.55 & $1.70-3.83$ & 1.78 & $1.13-2.81$ \\
\hline Frequently & 21.6 & 7.60 & $4.91-11.8$ & 3.62 & $2.08-6.28$ \\
\hline \multicolumn{6}{|c|}{ Delinquent behavior } \\
\hline Directly & * & & & & \\
\hline (Almost) Never & 5.5 & 1 & & 1 & \\
\hline Sometimes & 8.0 & 1.47 & $1.06-2.06$ & .71 & .47-1.08 \\
\hline Frequently & 15.5 & 3.13 & $1.83-5.35$ & .85 & $.42-1.74$ \\
\hline Indirectly & $*$ & & & & \\
\hline (Almost) Never & 4.9 & 1 & & 1 & \\
\hline Sometimes & 7.3 & 1.54 & $1.06-2.23$ & 1.04 & $.68-1.60$ \\
\hline Frequently & 12.9 & 2.87 & $1.85-4.47$ & 1.35 & $.75-2.44$ \\
\hline
\end{tabular}

$\mathrm{CI}$ indicates confidence interval.

$* P<.05$.

† Adjusted for sociodemographic variables, being bullied directly or indirectly, and bullying others directly and indirectly.

for girls, depression and suicidal ideation were more common among children who were sometimes or frequently being bullied directly. For boys, these associations did not persist in the multivariate analyses. For girls, these associations remained significant in multivariate analyses for depression (odds ratio 1.50 and 3.29 for sometimes and frequently being bullied directly) and for suicidal ideation (odds ratio 1.72 and 2.62 for sometimes and frequently being bullied directly). For example, of all girls who were frequently being bullied directly, $42.6 \%$ reported depression, compared with $6.4 \%$ for girls who were (almost) never being bullied directly.

Depression and suicidal ideation were also associated with being bullied indirectly. These associations persisted in multivariate analyses. This was true for boys as well as for girls. For boys, the odds ratios for those who were sometimes or frequently being bullied indirectly were 3.40 and 11.14 for depression and 2.09 and 5.58 for suicidal ideation. For girls, these odds ratios were 3.52 and 8.90 for depression and 1.78 and 3.62 for suicidal ideation. For example, $27.7 \%$ of frequently indirectly bullied boys showed depression symptoms compared with $2.1 \%$ of (almost) never indirectly bullied boys. For girls, these percentages were 35.1 and 3.6, respectively.

\section{Bullying Others and Psychosocial Health}

Results of the analyses of the associations between bullying others and indicators of psychosocial health are presented in Table 3 for boys and Table 4 for girls. Delinquent behavior was far more common in children who sometimes or frequently bullied other children directly. These associations persisted in multivariate analyses for boys (odds ratio 4.23 and 15.26 for sometimes and frequently bullying others directly) and for girls (odds ratio 3.57 and 10.75 for sometimes and frequently bullying others directly). For example, $37.7 \%$ of the boys and $30.6 \%$ of the girls who frequently bullied other children directly reported delinquent behavior, as opposed to $4.6 \%$ of the boys and $3.1 \%$ of the girls who (almost) never bullied other children directly.

Delinquent behavior was also more common in children who sometimes or frequently bullied other children indirectly. These associations, however, disappeared for the greatest part in multivariate analyses.

Furthermore, depression and suicidal ideation were also more common in children who sometimes or frequently bullied other children. This was true for both boys and girls and for bullying directly as well as indirectly. In multivariate analyses, however, most associations disappeared. For girls and for boys only a significant association still existed between bullying others directly and suicidal ideation. For boys, the odds ratios for those who were sometimes or frequently being bullied directly were 1.70 and 2.34; for girls these odds ratios were 1.48 and 2.66.

\section{DISCUSSION}

\section{Methodologic Considerations}

Before discussing the results, several aspects of the present study deserve comment. First, the overall response of the schools is relatively high compared 
TABLE 3. Crude and Adjusted Odds Ratios for the Association Between Bullying Others and Depression, Suicidal Ideation, and Delinquent Behavior, Respectively-Boys

\begin{tabular}{|c|c|c|c|c|c|}
\hline $\begin{array}{l}\text { Boys Bullying } \\
\text { Others }\end{array}$ & $\%$ & $\begin{array}{c}\text { Crude } \\
\text { Odds Ratio }\end{array}$ & $95 \%$ CI & $\begin{array}{c}\text { Adjusted } \\
\text { Odds Ratio† }\end{array}$ & $95 \% \mathrm{CI}$ \\
\hline \multicolumn{6}{|l|}{ Depression } \\
\hline Directly & * & & & & \\
\hline (Almost) Never & 4.3 & 1 & & 1 & \\
\hline Sometimes & 7.1 & 1.69 & $1.14-2.52$ & 1.07 & .69-1.66 \\
\hline Frequently & 11.9 & 2.97 & $1.87-4.70$ & 1.17 & $.67-2.03$ \\
\hline Indirectly & * & & & & \\
\hline (Almost) Never & 4.3 & 1 & & 1 & \\
\hline Sometimes & 7.9 & 1.90 & $1.31-2.75$ & 1.01 & $.67-1.53$ \\
\hline Frequently & 13.9 & 3.55 & $2.23-5.67$ & 1.25 & $.71-2.19$ \\
\hline \multicolumn{6}{|l|}{ Suicidal ideation } \\
\hline Directly & * & & & & \\
\hline (Almost) Never & 2.9 & 1 & & 1 & \\
\hline Sometimes & 6.4 & 2.33 & $1.47-3.71$ & 1.70 & $1.03-2.81$ \\
\hline Frequently & 10.7 & 4.08 & $2.42-6.89$ & 2.34 & $1.27-4.29$ \\
\hline Indirectly & $*$ & & & & \\
\hline (Almost) Never & 3.6 & 1 & & 1 & \\
\hline Sometimes & 7.0 & 2.00 & $1.34-2.98$ & 1.14 & $.74-1.77$ \\
\hline Frequently & 10.5 & 3.12 & $1.86-5.24$ & 1.14 & $.62-2.09$ \\
\hline \multicolumn{6}{|c|}{ Delinquent behavior } \\
\hline Directly & * & & & & \\
\hline (Almost) Never & 4.6 & 1 & & 1 & \\
\hline Sometimes & 15.3 & 3.76 & $2.63-5.37$ & 4.23 & $2.90-6.19$ \\
\hline Frequently & 37.7 & 12.61 & $8.58-18.5$ & 15.26 & $9.74-23.9$ \\
\hline Indirectly & $*$ & & & & \\
\hline (Almost) Never & 9.1 & 1 & & 1 & \\
\hline Sometimes & 16.7 & 1.99 & $1.53-2.60$ & 1.38 & $1.02-1.85$ \\
\hline Frequently & 31.9 & 4.68 & $3.33-6.57$ & 2.08 & $1.37-3.15$ \\
\hline
\end{tabular}

$\mathrm{CI}$ indicates confidence interval.

$* P<.05$.

† Adjusted for sociodemographic variables, being bullied directly and indirectly, and bullying others directly or indirectly.

with similar studies in The Netherlands. ${ }^{6,21}$ Additionally, sex and ethnic distribution of the sample is quite representative of the Amsterdam picture. ${ }^{22} \mathrm{Sec}-$ ond, data on bullying were collected by means of a self-report questionnaire, which is a common and valid method. ${ }^{23}$ Information about bullying can also be obtained from peers and teachers. They may identify different children as bullies or victims. However, when peer reports are compared with self-reports of the children concerned, high levels of agreement are found. Less agreement exists between teacher reports and self-reports, 1 of the reasons being that much of the bullying is covert and takes place when supervision is minimal. ${ }^{24-27}$ Third, no judgment can be made about the causal direction of the associations found, because of the cross-sectional nature of the study. Nevertheless, Olweus and colleagues ${ }^{15}$ found that even many years later victims of bullying still suffered from feelings of depression, and that offenders of bullying were more likely to commit offenses later in life. Other studies also support the view that bullying induces health problems rather than vice versa. ${ }^{13,28,29}$ Fourth, given the young age of the children, the data on mothers' and fathers' (un)employment might not be very reliable.

\section{Being Bullied and Psychosocial Health}

The present data emphasize that depression and suicidal ideation are common among victims of bullying at the age of 9 to 13 years, not only among girls but among boys as well. Moreover, this is the first study that reveals a relation between being bullied and suicidal ideation at this early age. Previous stud- ies among primary school children in Ireland, ${ }^{9}$ Australia, ${ }^{10}$ United Kingdom, ${ }^{11}$ and Finland ${ }^{12}$ also reported that victims of bullying had more depression symptoms than nonvictims. Despite the negative effect of bullying on mental health, many victimized children do not talk about it at home or report it to their teachers. ${ }^{2,4}$ Victims of bullying fear retaliation from the bully, are afraid they will not be believed, or perceive their situation in the long run as normal. As a result, bullying can take place for many years without being noticed by adults. ${ }^{30}$

The impact of being bullied on depression was higher for indirect than direct bullying. This was the case for both girls and boys. This interesting finding challenges the belief that direct (physical) bullying causes more harm and is more socially unacceptable than indirect bullying (social isolation). In line with our study, Crick and Grotpeter ${ }^{31}$ found among 474 children in grades 3 to 6 that relational victimization is more strongly related to maladjustment, such as depression and loneliness, than is overt victimization. Paquette and Underwood ${ }^{32}$ found in a subsample of adolescents who were able to recall specific aggression incidents in which they were the victims of both social and physical aggression, that social aggression made them feel more sad and bad about themselves than did physical aggression. Indirect forms of bullying probably cause the greatest amount of suffering, while they have a greater chance of going unnoticed by teachers. Indirect bullying is less visible and thus difficult to prove. This is perhaps the reason why boys as well as girls are much less inclined to tell an adult about indirect 
TABLE 4. Crude and Adjusted Odds Ratios for the Association Between Bullying Others and Depression, Suicidal Ideation, and Delinquent Behavior, Respectively-Girls

\begin{tabular}{|c|c|c|c|c|c|}
\hline $\begin{array}{l}\text { Girls Bullying } \\
\text { Others }\end{array}$ & $\%$ & $\begin{array}{c}\text { Crude } \\
\text { Odds Ratio }\end{array}$ & $95 \%$ CI & $\begin{array}{c}\text { Adjusted } \\
\text { Odds Ratio }\end{array}$ & $95 \% \mathrm{CI}$ \\
\hline \multicolumn{6}{|l|}{ Depression } \\
\hline Directly & * & & & & \\
\hline (Almost) Never & 9.7 & 1 & & 1 & \\
\hline Sometimes & 16.0 & 1.76 & $1.37-2.27$ & 1.12 & $.84-1.50$ \\
\hline Frequently & 23.5 & 2.84 & $1.73-4.68$ & 1.25 & $.68-2.28$ \\
\hline Indirectly & $*$ & & & & \\
\hline (Almost) Never & 8.4 & 1 & & 1 & \\
\hline Sometimes & 14.0 & 1.79 & $1.34-2.39$ & .98 & $.70-1.36$ \\
\hline Frequently & 19.2 & 2.61 & $1.79-3.81$ & .75 & $.47-1.20$ \\
\hline \multicolumn{6}{|l|}{ Suicidal ideation } \\
\hline Directly & * & & & & \\
\hline (Almost) Never & 5.4 & 1 & & 1 & \\
\hline Sometimes & 11.2 & 2.21 & $1.62-3.02$ & 1.48 & $1.04-2.10$ \\
\hline Frequently & 24.5 & 5.69 & $3.40-9.51$ & 2.66 & $1.43-4.95$ \\
\hline Indirectly & $*$ & & & & \\
\hline (Almost) Never & 5.1 & 1 & & 1 & \\
\hline Sometimes & 8.8 & 1.80 & $1.26-2.58$ & 1.03 & $.69-1.55$ \\
\hline Frequently & 15.8 & 3.51 & $2.27-5.42$ & 1.05 & $.61-1.80$ \\
\hline \multicolumn{6}{|c|}{ Delinquent behavior } \\
\hline Directly & * & & & & \\
\hline (Almost) Never & 3.1 & 1 & & 1 & \\
\hline Sometimes & 11.1 & 3.92 & $2.71-5.66$ & 3.57 & $2.35-5.41$ \\
\hline Frequently & 30.6 & 13.87 & $8.21-23.4$ & 10.75 & $5.60-20.6$ \\
\hline Indirectly & * & & & & \\
\hline (Almost) Never & 3.0 & 1 & & 1 & \\
\hline Sometimes & 7.9 & 2.72 & $1.76-4.21$ & 1.66 & $1.02-2.68$ \\
\hline Frequently & 16.2 & 6.13 & $3.74-10.0$ & 2.09 & $1.14-3.83$ \\
\hline
\end{tabular}

$\mathrm{CI}$ indicates confidence interval.

$* P<.05$.

+ Adjusted for sociodemographic variables, being bullied directly and indirectly, and bullying others directly or indirectly.

forms of bullying. ${ }^{4}$ In addition, many teachers do not consider social exclusion a form of bullying, ${ }^{33}$ or consider this form of bullying as less harmful. ${ }^{34}$ For these reasons, interventions at primary schools to stop bullying must pay special attention to indirect forms of bullying.

After correction, we found among boys no significant association between being bullied directly and depression, whereas among girls there was a strong association. The same was true for suicidal ideation. These findings are in agreement with the study of Crick and Grotpeter ${ }^{31}$ based on peer reports. They stated in a footnote that for boys, overt victimization did not add to relational victimization in the prediction of depression, but it did so for girls. Unfortunately, we could not find other reference data to validate our findings. The gender difference mentioned can perhaps partly be explained by the fact that boys, contrary to girls, view physical bullying as acceptable and sometimes idealized behavior. ${ }^{35}$

\section{Bullying Others and Psychosocial Health}

Offenders of bullying more often reported delinquent behavior. After statistically controlling for confounding variables, this association still existed. Moreover, bullying others directly is a much greater risk factor for delinquent behavior than bullying others indirectly. This holds for boys as well as girls. Other studies also found that delinquent behavior is more common among bullies.6,15 However, these studies were (mainly) conducted among secondary school children, and no distinction was made between bullying directly and indirectly. It is believed that bullying among adolescents is an expression of a more general aggressive attitude, which shows considerable stability over the years. ${ }^{1}$ This tendency to aggression is generally viewed as part of a broader syndrome of serious antisocial and delinquent behavior. ${ }^{25,36}$ On the basis of our findings we can postulate that this deviant behavior pattern, which includes (direct) bullying as well as delinquency, may be present already at the end of primary school. It should be noted, however, that at this age the rates of offending are considerably lower and the offenses less serious. ${ }^{6}$ On the other hand, early onset of delinquent behavior is a risk factor for chronicity of offending. ${ }^{37}$ Furthermore, screening on direct bullying (aggressive) behavior rather than on general bullying (aggressive) behavior probably increases predictive validity to identify children at greatest risk of becoming delinquent.

Offenders of bullying also more often reported depressive symptoms and suicidal ideation. However, associations between bullying others and depression vanished after adjustment. It is most likely that depression symptoms among bullies are mainly the result of being bullied themselves. As a reaction to being bullied, these children bully back to defend themselves or bully others to bolster their own selfimage. Some previous studies also reported more depression and suicidal ideation among bullies.7,8,10 It is unclear whether these associations would remain if the level of being bullied had been (totally) controlled. It is quite possible that depressive bullies need a different intervention than nondepressive bullying children. 


\section{CONCLUSIONS}

The association between bullying and psychosocial health differed notably between girls and boys as well as between direct and indirect forms of bullying. Antibullying interventions in primary schools must pay attention to these differences to successfully prevent the development of emotional problems, such as depression and suicidal ideation, or the beginning of a criminal career.

\section{REFERENCES}

1. Farrington DP. Understanding and preventing bullying. In: Tonry M, ed. Crime and Justice: A Review of Research. Chicago, IL: University of Chicago Press, 1993:381-458

2. Whitney I, Smith PK. A survey of the nature and extent of bullying in junior/middle and secondary schools. Educ Res. 1993;35:3-25

3. Borg MG. The extent and nature of bullying among primary and secondary schoolchildren. Educ Res. 1999;41:137-153

4. Rivers I, Smith PK. Types of bullying behaviour and their correlates. Aggress Behav. 1994;20:359-368

5. Björkqvist K, Lagerspetz KMJ, Kaukiainen A. Do girls manipulate and boys fight? Developmental trends in regard to direct and indirect aggression. Aggress Behav. 1992;18:117-127

6. Junger-Tas J, Van Kesteren J. Bullying and Delinquency in a Dutch School Population. The Hague, The Netherlands: Kugler Publications; 1999

7. Salmon G, James A, Smith DM. Bullying in schools: self reported anxiety, depression and self esteem in secondary school children. BMJ. 1998;317:924-925

8. Kaltiala-Heino R, Rimpelä M, Marttunen M, Rimpelä A, Rantanen P. Bullying, depression, and suicidal ideation in Finnish adolescents: school survey. BMJ. 1999;319:348-351

9. Neary A, Joseph S. Peer victimization and its relationship to selfconcept and depression among schoolgirls. Pers Individ Diff. 1994;16: 183-186

10. Slee PT. Peer victimization and its relationship to depression among Australian primary school students. Pers Individ Diff. 1995;18:57-62

11. Williams K, Chambers M, Logan S, Robinson D. Association of common health symptoms with bullying in primary school children. BMJ. 1996; 313:17-19

12. Kumpulainen $K$, Räsänen E, Henttonen I, et al. Bullying and psychiatric symptoms among elementary school-age children. Child Abuse Negl. 1998;22:705-717

13. Bond L, Carlin JB, Thomas L, Rubin K, Patton G. Does bullying cause emotional problems? A prospective study of young teenagers. BMJ 2001;323:480-484

14. Nansel TR, Overpeck M, Pilla RS, Ruan WJ, Simons-Morton B, Scheidt $\mathrm{P}$. Bullying behaviors among US youth: prevalence and association with psychosocial adjustment. JAMA. 2001;285:2094-2100

15. Olweus D. Bullying at School: What We Know and What We Can Do Oxford, United Kingdom: Blackwell; 1993

16. Van der Wal MF, Uitenbroek DG. De Amsterdamse pestvragenlijst voor kinderen. Tijdschrift voor Gezondheidswetenschappen. 2001;79:86-89

17. De Wit CAM. Depressie Vragenlijst Voor Kinderen. DVK en KDVK. Handleiding. Amersfoort/Leuven, The Netherlands: Acco; 1987

18. Meier P, Mellenbergh G, De Wit CAM. De Korte Depressie Vragenlijst voor Kinderen (KDVK). Ned Tijdschr Psychol. 1986;41:364-368

19. De Wit CAM, Kroesbergen HT. Depressieve klachten bij kinderen: vroegtijdige onderkenning en hulpverlening. Tijdschr Soc Gezondheidsz. 1992;70:477-483

20. Kroesbergen HT, De Wit CAM, Stijnen TH. Detection of depressive complaints in children. Eur J Public Health. 1996;6:29-34

21. Mooij T. Pesten in Het Onderwijs. Nijmegen, The Netherlands: Instituut voor Toegepaste Sociale wetenschappen; 1992

22. Van der Wal MF, Diepenmaat ACM, Pauw-Plomp H, Van WeertWaltman ML. Hoge vaccinatiegraad van Amsterdamse kinderen. Ned Tijdschr Geneeskd. 2001;145:131-135

23. Ahmad Y, Smith PK. Behavioural measures review: bullying in schools. Newsl Association Child Psychol Psychiatry. 1990;12:26-27

24. Pellegrini AD, Bartini M. An empirical comparison of methods of sampling aggression and victimization in school settings. J Educ Psychol. 2000;92:360-366

25. Olweus D. Bullying at school: basis facts and effects of a school based intervention program. J Child Psychol Psychiatry. 1994;35:1171-1190

26. Österman K, Björkqvist K, Lagerspetz KMJ, Kaukiainen A, Huesman LR, Fraczek A. Peer and self-estimated aggression and victimization in 8-year-old children from five ethnic groups. Aggress Behav. 1994;20: 411-428

27. Rigby K, Slee PT. Bullying among Australian school children: reported behavior and attitudes towards victims. J Soc Psychol. 1991;131:615-627

28. Kochenderfer BJ, Ladd GW. Peer victimization: cause or consequence of school maladjustment? Child Dev. 1996;67:1305-1317

29. Sharp S. How much does bullying hurt? The effects of bullying on the personal well-being and educational progress of secondary aged students. Educ Child Psychol. 1995;12:81-88

30. Smith PK. The silent nightmare: bullying and victimisation in school peer groups. Psychologist. 1991;4:243-248

31. Crick NR, Grotpeter JK. Children's treatment by peers: victims of relational and overt aggression. Dev Psychopathol. 1996;8:367-380

32. Paquette JA, Underwood MK. Gender differences in young adolescents' experiences of peer victimization: social and physical aggression. Merill Palmer Q. 1999;45:242-266

33. Boulton MJ. Teachers' views on bullying: definitions, attitudes and ability to cope. Br J Educ Psychol. 1997;67:223-233

34. Van Hattum MJC. Pesten: Een Onderzoek Naar Beleving, Visie en Handelen van Leraren en Leerlingen [proefschrift]. Amsterdam, The Netherlands: Universiteit van Amsterdam; 1997

35. Huesmann LR, Guerra NG, Zelli A, Miller L. Differing normative beliefs about aggression for boys and girls. In: Björkqvist K, Niemelä P, eds. Of Mice and Women: Aspects of Female Aggression. San Diego, CA: Academic, 1992; 77-87

36. Loeber R. Development and risk factors of juvenile antisocial behavior and delinquency. Clin Psychol Rev. 1990;10:1-41

37. Loeber R. The stability of antisocial and delinquent child behavior. Child Dev. 1982;53:1431-1446 


\section{Psychosocial Health Among Young Victims and Offenders of Direct and Indirect Bullying \\ Marcel F. van der Wal, Cees A. M. de Wit and Remy A. Hirasing Pediatrics 2003:111:1312}

\section{Updated Information \& Services}

References

Citations

Subspecialty Collections

Permissions \& Licensing

Reprints including high resolution figures, can be found at: http://pediatrics.aappublications.org/content/111/6/1312.full.h tml

This article cites 30 articles, 5 of which can be accessed free at:

http://pediatrics.aappublications.org/content/111/6/1312.full.h tml\#ref-list-1

This article has been cited by 23 HighWire-hosted articles: http://pediatrics.aappublications.org/content/111/6/1312.full.h tml\#related-urls

This article, along with others on similar topics, appears in the following collection(s):

\section{Office Practice}

http://pediatrics.aappublications.org/cgi/collection/office_pra ctice

Information about reproducing this article in parts (figures, tables) or in its entirety can be found online at: http://pediatrics.aappublications.org/site/misc/Permissions.xht $\mathrm{ml}$

Information about ordering reprints can be found online: http://pediatrics.aappublications.org/site/misc/reprints.xhtml

PEDIATRICS is the official journal of the American Academy of Pediatrics. A monthly publication, it has been published continuously since 1948. PEDIATRICS is owned, published, and trademarked by the American Academy of Pediatrics, 141 Northwest Point Boulevard, Elk Grove Village, Illinois, 60007. Copyright @ 2003 by the American Academy of Pediatrics. All rights reserved. Print ISSN: 0031-4005. Online ISSN: 1098-4275.

\section{American Academy of Pediatrics}

DEDICATED TO THE HEALTH OF ALL CHILDREN ${ }^{\mathrm{m}}$ 